Egyptian Journal of Rabbit Science, 26(2): 281 -299 (2016)

\title{
EFFECT OF CARVACROL ON PRODUCTIVE PERFORMANCE AND SOME IMMUNOLOGICAL PARAMETERS OF GROWING RABBITS
}

\author{
Amal M. Hekal'; A.M.M. Saidahmed ${ }^{1}$; Fadila M. Easa ${ }^{1}$; W.A.H. Ali \\ and S. M. M. Mousa ${ }^{2}$ \\ 1-Department of Rabbit; Turkey and Water Fowl Breeding Research \\ 2-Department of Poultry Breeding Research, Animal Production Research \\ Institute, Agricultural Research Center, Giza, Egypt. \\ E-mail of Corresponding Author:dramalmaghawry@yahoo.com
}

A total number of $40 \mathrm{New}$ Zealand White rabbit males at 4 weeks of age and averaged $542.50 \mathrm{~g}$ body weight were used in this study. Animals were distributed randomly into four experimental groups (10 rabbits each). The $1^{\text {st }}$ group was served as a control group without any supplementation in drinking water. Whereas, the carvacrol was added with concentrations of 0.13, 0.26 and 0.39 $\mathrm{ml} /$ liter in drinking water for representing the $2^{\text {nd }}, 3^{\text {rd }}$ and $4^{\text {th }}$ groups, respectively. The experiment lasted for 8 weeks. The obtained results could be summarized as follows: rabbit males supplied with $0.26 \mathrm{ml}$ carvacrol/liter had the best value for live body weight and live body weight gain followed by rabbit provided 0.39 and $0.13 \mathrm{ml}$ carvacrol/liter, respectively compared with the control group. Supplementation with 0.13 and $0.39 \mathrm{ml}$ carvacrol/liter improved significantly $(P \leq 0.05)$ feed conversion ratio compared with other groups $(0.26 \mathrm{ml}$ carvacrol/liter and control). There were significantly $(P \leq 0.05)$ increased in the erythrocytes and leukocytes counts, and hemoglobin, hematocrit value and lymphocytes percentage due to providing rabbit different levels of carvacrol. Rabbits supplemented $0.39 \mathrm{ml}$ carvacrol/liter recorded the highest counts of both erythrocytes and leukocytes, and hemoglobin, hematocrit value and lymphocytes percentage, followed by rabbits provided 0.26 and $0.13 \mathrm{ml}$ carvacrol/liter, respectively. Providing rabbit different levels of carvacrol significantly $(P \leq 0.05)$ improved neutrophil/ lymphocytes ratio compared to control rabbits. Generally, rabbits drinking $0.39 \mathrm{ml}$ carvacrol/liter recorded the best value of neutrophil/ lymphocytes ratio, followed by rabbits drinking 0.26 and $0.13 \mathrm{ml}$ carvacrol/liter, respectively, compared to control group. Providing rabbit different levels of carvacrol significantly 
$(P \leq 0.05)$ reduced the total counts of anaerobic and E. coli bacteria, at the same time they increased the beneficial bacteria counts (lactobacillus), rabbits supplemented $0.39 \mathrm{ml}$ carvacrol/liter recorded the lowest count of both anaerobic and E. coli bacteria, and the highest count of lactobacillus followed by rabbits drinking 0.26 and $0.13 \mathrm{ml}$ carvacrol/liter, respectively. It could be concluded that drinking rabbit different levels of carvacrol significantly improved the growth performance, carcass characteristic and some immunological parameters of growing rabbit males.

Keywords: Carvacrol, rabbits, productive performance, carcass traits, immunological parameters.

Carvacrol is a monoterpenoid phenol predominantly found in oregano (Origanum vulgare), thyme (Thymus vulgaris), pepperwort (Lepidium fla-vum) and wild bergamot, also produced naturally by isolation of essential oil from some plants (Jamali et al., 2012 and Kim et al., 2013). Several studies in vitro and in vivo described different bioactivity of carvacrol nutrient, including antibacterial, antioxidant, antiseptic, antispasmodic, growth promoter, antifungal, antiviral, anti-inflammatory, expectorant, antitussive, immunomodulatory and chemopreventive as well as modifier of rumen microbial fermentation and reduction of methane emission (Hashemipour et al., 2013 and Bravo et al., 2014). Carvacrol is molecule that has crucial bioactivities on poultry and animal physiology and metabolism (Reiner et al., 2009), this compound could have antioxidant action on poultry meat when added in the diet. Carvacrol plays a critical role as natural antioxidant in the reduction of lipid peroxidation which leading to oxidative destruction of cellular membranes (Rhee et al., 1996; Yanishlieva et al., 1999). Several studies have been reported the addition of some phytogenic additives or their products such as cold pressed oil, essential oil or extracts to animal and poultry diets that improved live body weight, body weight gain, feed conversion ratio, immune response, antioxidant status, carcass traits and quality, and lowered morbidity and mortality rates (Ashour et al., 2014; Farag et al., 2014; Alagawany et al., 2015a, 2015b; Dhama et al., 2015). Carvacrol inhibits the growth of several bacteria strains, e.g. Escherichia coli and Bacillus cereus (Du et al., 2008). Its low toxicity together with its pleasant taste and smell suggests its use as a feed additive to prevent bacterial contamination (Ultee and Smid, 2001). In Pseudomonas aeruginosa it causes damages to the cell membrane of these bacteria and, unlike other terpenes, inhibits the proliferation of this germ (Cox and Markham, 2007). 
Oregano (Origanum vulgare L.) is an aromatic plant with a wide distribution throughout the mediterranean area and Asia (Vokou et al., 1993). The essential oil obtained from Origanum vulgare subsp. hirtum plant by a steam distillation process comprises more than 20 ingredients, most of which are phenolic antioxidants (Vekiari et al., 1993).

Major components are carvacrol and thymol that constitute about 78 to $82 \%$ of the total oil (Adam et al., 1998). It has been suggested that the essential oil derived from oregano possess in vitro antimicrobial (Lambert et al., 2001), antifungal (Thompson, 1989), insecticidal (Karpouhtsis et al., 1998) and antioxidant (Botsoglou et al., 2002) properties. These properties are mainly attributed to carvacrol and thymol. The activity of other constituents such as the two monoterpene hydrocarbons, Y-terpinene and pcymene, that often constitute about 5 and $7 \%$ of the total oil, respectively (Adam et al., 1998). However, the oregano plants, apart from these volatile phenolic antioxidant compounds occurring in the essential oil (Adam et al., 1998), contain a variety of glycosidically bound volatile and non-volatile constituents that also exhibit biological activity after enzymatic or acid hydrolysis (Milos et al., 2000).

Therefore, oregano plants might be more biologically active than their essential oil when incorporated in poultry diets. Radwan and Abdel - Khalek (2007) suggested that the herb mixture of equal parts of sage and oregano at $0.5 \%$ supplementation level increased both of villi height, crypt depth and absorption area and improved growth and health of growing rabbits. The phenolic compounds carvacrol and thymol present in the essential oil from oregano has a good antioxidant capacity and also, antimicrobial activity against pathogenic microorganisms like Salmonella typhimurium, Escherichia coli, Staphylococcus aureus and Staphylococcus epidermidis (Arcila-Lozano et al., 2004).

Therefore, this is study was conducted to investigate the effect of carvacrol on the productive performance and some immunological parameters of growing rabbits.

\section{MATERIALS AND METHODS}

The current experiment was carried out to highlight on the effect of carvacrole supplementation on productive performance, carcass characteristics, bacteria count and hematological picture of growing rabbit males.

\section{Animals and experimental design}

A total number of 40 New Zealand White rabbit (NZW) males at 4 weeks of age and averaged $542.50 \mathrm{~g}$ body weight were used in this study. Animals were distributed randomly into four experimental groups (10 
rabbits each). The $1^{\text {st }}$ group was without any supplementation in drinking water and served as a control group. Whereas, the carvacrol was added with concentrations of $0.13,0.26$ and $0.39 \mathrm{ml} /$ liter in drinking water for representing the $2^{\text {nd }}, 3^{\text {rd }}$ and $4^{\text {th }}$ groups, respectively. The three levels of carvacrol were obtained from $0.2,0.4$ and $0.6 \mathrm{ml}$ oregano/liter, respectively.

\section{Managements and feeding:}

Rabbits individually housed in galvanized wire cages $(30 \times 35 \times 40$ $\mathrm{cm})$. Stainless steel nipples for drinking and feeders allowing recording individual feed intake for each rabbit were supplied for each cage. Rabbits of all groups were kept under the same managerial conditions. A period of 16 hours of day light was provided. Feed and water were available $a d$ libitum during the experimental period. The basal ration that met all the requirements recommended by NRC (1994) was fed to animal in the control and treatments groups. The chemical composition of the basal diets was presented in Table 1 .

\section{Measurements:-}

\section{Performance traits:-}

Individual live body weight (LBW) was recorded at 4 wks of age and then weekly up to 12 wks of age then live body weight gain (LBWG) calculated. Feed intake (FI) was recorded and feed conversion ratio (FCR) was calculated during the same previous intervals.

\section{Carcass traits:-}

At the end of the experimental period at (12 weeks of age), three rabbits from each group were randomly taken, fasted for 12 hours, weighed individually and slaughtered to complete bleeding (Cheeke, 1987). After bleeding, rabbits were weighed and skinned. After slaughtering and skinning the carcasses were eviscerated. Relative weights of carcass, head and edible offal's (Giblets) included heart, liver, kidneys, spleen and lungs were measured. Empty weight and length of small intestine were also recorded.

\section{Blood picture:-}

During slaughtering, about $5 \mathrm{ml}$ blood samples, were drawn from slaughtered rabbit and tested shortly after collection for estimating blood picture. The total count of red and white blood cells, as well as, the differential counts of leucocytes (lymphocyte and neutrophil) were counted 
Table 1: Composition of basal diets:

\begin{tabular}{|l|c|}
\hline Ingredients & \% \\
\hline Yellow corn & 22.80 \\
Soybean Meal-44 & 18.10 \\
Guar korma meal & 0.00 \\
Alfalfa hay & 27.25 \\
Wheat bran & 25.35 \\
Molass & 3.00 \\
Dical. Phos. & 1.90 \\
Salt & 0.30 \\
Premix* & 0.30 \\
DL-Methionine & 0.30 \\
Lime stone & 0.70 \\
\hline Total & $\mathbf{1 0 0}$ \\
\hline Calculated contents: & \\
Crude Protein (CP \%) & 17.09 \\
Detestable Energy kcal/g & 2541.39 \\
Crude Fiber (CF \%) & 12.81 \\
Ether extract (EE \%) & 2.73 \\
Calcium, \% & 1.18 \\
Tot. Phosphorus, \% & 0.83 \\
Avil. Phosphorus, \% & 0.41 \\
Lysine, \% & 0.89 \\
Methionine, \% & 0.57 \\
Met + Cys, \% & 0.86 \\
Na & 0.16 \\
\hline
\end{tabular}

* The vitamin mineral premix added to $1 \mathrm{~kg}$ of the experimental diets contains: Vitamin A: 10.000IU; Vitamin D3: 2.000IU; Vitamin E: 10mg; Vitamin K: 2mg; Vitamin B1: 1mg; Vitamin B2: 5mg; Vitamin B6: $1.5 \mathrm{mg}$; Vitamin B12: 10 microgram; Pantothenic: 10mg; Niacin: $30 \mathrm{mg}$; Folic acid: 1mg; Biotin: 50microgram; Choline chloride: $250 \mathrm{mg}$; Iron: 30mg; Manganese: 60mg; Copper: 4mg; Iodine: 0.3mg; Cobalt: 0.1mg; Zinc: 50mg and Selenium: $0.1 \mathrm{mg}$.

according to Feldman et al., (2000). Hemoglobin concentration was measured according to (Drew et al. 2004).

\section{Microbiological analysis:-}

Cecum contents for slaughtered rabbits were separately collected for each treatment under aseptic conditions to determine the total count of anaerobic bacteria and Escherichia coli (E.Coli) in their selective media as described by Collins et al., (1995) and lactobacilli bacteria count in their selective media as described by Kim and Goepfert (1971). 
Statistical analysis:

Data were subjected to one-way analysis of variance using SAS (2001). Differences among means were tested by using Duncan's multiple range test (Duncan, 1955). The percentage values were transferred to percentage angle using arcsine equation before subjected to statistical analysis, and then actual means are presented. The following model was used: $\mathrm{Yij}=\mathrm{G}+\mathrm{Ti}+$ eij.

Where, Yij = observation for each dependent variable; $\mathrm{G}=$ General mean; $\mathrm{Ti}=$ Treatment effects $(\mathrm{i}=1,2 \ldots$ and 4$) ;$ eij $=$ Random error .

\section{RESULTS AND DISCUSSION}

\section{Growth performance:-}

Performance parameters of growing rabbit males as influenced by drinking carvacrol are illustrated in Table 2 . Body weight of rabbits at 4 wks of age was nearly similar between the drinking treatments. At 8 wks of age, body weight of rabbits drinking $0.39 \mathrm{ml}$ carvacrol/liter was significantly $(\mathrm{P} \leq 0.05)$ increased compared to the other groups. Similar trend was observed in body weight at the end of the experiment (12 wks of age) of rabbits drinking 0.26 and $0.39 \mathrm{ml}$ carvacrol/liter respectively compared to control group. Body gain of growing rabbit males drinking different levels of carvacrol significantly $(\mathrm{P} \leq 0.5)$ increased as compared to the control group during 8-12 wks of age and whole experimental period (4-12 wks of age), where rabbits supplemented $0.26 \mathrm{ml}$ carvacrol/liter showed a significantly $(\mathrm{P} \leq 0.05)$ highest gain compared to control one, while those supplemented 0.13 and $0.39 \mathrm{ml}$ carvacrol/liter showed the lowest gain (Table 2). During 4-8 wks of age, rabbits received 0.13 and $0.39 \mathrm{ml}$ carvacrol/liter consumed significantly $(\mathrm{P} \leq 0.05)$ less feeds compared to other two treatments. Thereafter, during 8-12 wks of age, the treatments had no significant effects on feed intake of rabbits. Generally, total feed intake for the whole experimental period was significantly $(\mathrm{P} \leq 0.05)$ higher for rabbits received $0.26 \mathrm{ml}$ carvacrol/liter compared to the other groups, while, rabbits drinking $0.13 \mathrm{ml}$ carvacrol/liter showed the lowest feed intake compared to the other groups.

Concerning the feed conversion ratio, rabbits supplemented 0.13 and 0.39 $\mathrm{ml}$ carvacrol/liter significantly $(\mathrm{P} \leq 0.05)$ improved feed conversion ratio compared to the rabbits received $0.26 \mathrm{ml}$ carvacrol/liter or control group during 4-8 and 4-12 wks of age. Generally, during period (8-12 wks of age), feed conversion ratio was significantly $(\mathrm{P} \leq 0.05)$ improved with drinking different carvacrol levels compared to those drinking the control water 
Table 2: Effect of drinking supplementation of carvacrol on the performance of growing rabbit males during the experimental period.

\begin{tabular}{|c|c|c|c|c|c|}
\hline \multirow[t]{2}{*}{ Item } & \multicolumn{4}{|c|}{ Experimental groups } & \multirow[t]{2}{*}{ MSE } \\
\hline & G1 & G2 & G3 & G4 & \\
\hline \multicolumn{6}{|c|}{ Live body weight (g): } \\
\hline $4 \mathrm{wk}$ & 540.00 & 535.00 & 535.00 & 560.00 & 13.794 \\
\hline $8 \mathrm{wk}$ & $1405.00^{b}$ & $1425.00^{b}$ & $1420.00^{b}$ & $1485.00^{\mathrm{a}}$ & 28.361 \\
\hline $12 \mathrm{wk}$ & $2075.00^{b}$ & $2165.00^{\mathrm{ab}}$ & $2235.00^{\mathrm{a}}$ & $2215.00^{\mathrm{ab}}$ & 51.424 \\
\hline \multicolumn{6}{|c|}{ Live body weight gain (g): } \\
\hline $4-8 \mathrm{wk}$ & 865.00 & 890.00 & 885.00 & 925.00 & 38.397 \\
\hline $8-12 \mathrm{wk}$ & $670.00^{\mathrm{b}}$ & $740.00^{\mathrm{ab}}$ & $815.00^{\mathrm{a}}$ & $730.00^{\mathrm{ab}}$ & 43.341 \\
\hline $4-12 \mathrm{wk}$ & $1535.00^{b}$ & $1630.00^{\mathrm{ab}}$ & $1700.00^{\mathrm{a}}$ & $1655.00^{\mathrm{ab}}$ & 52.665 \\
\hline \multicolumn{6}{|c|}{ Feed intake (g/rabbit): } \\
\hline $4-8 w k$ & $1945.00^{\mathrm{a}}$ & $1765.00^{\mathrm{b}}$ & $1985.00^{\mathrm{a}}$ & $1715.00^{\mathrm{b}}$ & 50.360 \\
\hline $8-12 w k$ & 3275.00 & 3220.00 & 3720.00 & 3325.00 & 69.707 \\
\hline $4-12 \mathrm{wk}$ & $5220.00^{b}$ & $4985.00^{b}$ & $5705.00^{\mathrm{a}}$ & $5040.00^{b}$ & 82.454 \\
\hline \multicolumn{6}{|c|}{ Feed conversion ratio (feed intake, g/weight gain, $g$ ): } \\
\hline $4-8 \mathrm{wk}$ & $2.277^{\mathrm{a}}$ & $2.002^{\mathrm{b}}$ & $2.301^{\mathrm{a}}$ & $1.872^{\mathrm{b}}$ & 0.078 \\
\hline $8-12 \mathrm{wk}$ & $5.174^{\mathrm{a}}$ & $4.456^{\mathrm{b}}$ & $4.634^{\mathrm{b}}$ & $4.664^{\mathrm{b}}$ & 0.089 \\
\hline 4-12 wk & $3.415^{\mathrm{a}}$ & $3.080^{\mathrm{b}}$ & $3.374^{\mathrm{a}}$ & $3.084^{\mathrm{b}}$ & 0.091 \\
\hline
\end{tabular}

Means within each row have no similar letter(s) are significantly different $(\mathrm{P} \leq 0.05)$ G1: Control G2: carvacrol ( $0.13 \mathrm{ml} /$ liter $)$ G3: carvacrol ( $0.26 \mathrm{ml} /$ liter $) \mathrm{G} 4$ : carvacrol $(0.39 \mathrm{ml} / \mathrm{liter})$.

(Table 2). In this respect, Ibrahim et al., (2000) and Ibrahim et al., (2002) found that dietary $0.5 \%$ oregano significantly increased weight gain, feed intake, and improved feed conversion of rabbits. Also, Omer et al. (2013) showed that rabbits received $2 \%$ oil $+0.5 \%$ fennel seeds $+0.5 \%$ oregano leaves containing diets recorded the best final weight, body weight gain, average daily gain and feed conversion ratio compared to other treatments or control groups. On the other hand, Radwan and Abdel-Khalek (2007) supplemented $0.5 \%$ a herb mixture of equal parts of sage+oregano+sweet basal or $1.0 \%$ of the previous herb mixture to investigate the response to some growth promoters as safe alternatives to antibiotics on some performance aspects of rabbits. They revealed that total weight gain $(\mathrm{P} \leq 0.01)$ and feed conversion ratio $(\mathrm{P} \leq 0.05)$ were improved. The improvement occurred may be due to synergistic properties of different oils (Moleyar and Narasimham, 1992). Conversely, Botsoglou et al. (2004) fed rabbits on diets supplemented with oregano essential oil at levels of 100 and $200 \mathrm{mg} / \mathrm{kg}$ diet, whereas the remaining group was given a diet supplemented with $\alpha$-tocopheryl acetate at $200 \mathrm{mg} / \mathrm{kg}$. They noted that body 
weight, feed intake feed conversion ratio were not affected. Therefore, dietary oregano essential oil exerted no growth-promoting effect on rabbits. However, Untea et al. (2011) found that supplementation 3\% of oregano in weaned piglet's diet resulted in significant differences between the control and experimental groups.

The highest feed conversion ratio was recorded with adding oregano. Roofchaee et al. (2011) found that supplementation of $600 \mathrm{mg} / \mathrm{kg}$ of oregano essential oil in the grower period significantly $(\mathrm{P} \leq 0.05)$ increased body weight gain compared with the control group, while, feed intake was not significantly influenced by dietary inclusion of oregano essential oil in any of the growth periods broilers. Moreover, feed conversion ratio was not affected by dietary supplementation of oregano essential oil in starter period, but inclusion of 600 and $1200 \mathrm{mg} / \mathrm{kg}$ of oregano essential oil in grower period significantly $(\mathrm{P} \leq 0.05)$ improved feed conversion ratio compared with control group. Abdel-Wareth (2011) found that feed conversion ratio was positively affected 15 or $20 \mathrm{~g} / \mathrm{kg}$ oregano. However, when $30 \mathrm{~g} / \mathrm{kg}$ oregano were added the feed conversion ratio increased by approximately $5 \%$.

A blend derived from oregano, clove and anise essential oil supplemented at a level of $200 \mathrm{mg} / \mathrm{kg}$ resulted in an increased BW gain by $16 \%$, as well as, an improved FCR by $12 \%$. It was concluded that these positive findings were due to the positive digestive stimulating effects of thymol and carvacrol (Ertas et al., 2005). In agreement with this study, Lee et al. (2003a) found that some bioactive components of essential oils especially carvacrol, improved feed conversion ratio in broiler chickens. They proposed that the effect of carvacrol on feed conversion ratio could be related to increased efficiency of feed utilization. Also, Mansoub (2011) found that the highest $(\mathrm{P} \leq 0.05)$ amount of body weight gain and the lowest $(\mathrm{P} \leq 0.05)$ level of feed conversion ratio were observed in the group received 200 ppm of oregano oil, but, the best $(\mathrm{P} \leq 0.05)$ result for daily feed intake was in the group received $150 \mathrm{ppm}$ of oregano oil.

The beneficial effect of growth promoting feed additives on animals arises from stabilizing feed hygiene and beneficially modulating the gut ecosystemby controlling potential pathogens. Phytogenic compounds have a number of active ingredients and pharmacologically active substances that are beneficial for maintaining health and improving performance of poultry and other livestock species. They are reported to stimulate secretion of digestive enzymes (lipase and amylase) and intestinal mucous in broilers, to stimulate feed digestion, to impair adhesion of pathogens and to stabilize microbial balance in the gut (Lee et al., 2003a). On the other hand, Soultos 
et al. (2009) supplemented rabbit diets with oregano essential oil at levels of 0,100 and $200 \mathrm{mg} / \mathrm{kg}$ diet, respectively. They found no significantly effect on rabbit performance parameters (final live body weights, average daily gain and feed conversion ratio). Also, Botsoglou et al., (2004) reported that dietary oregano essential oil (100 or $200 \mathrm{mg} / \mathrm{kg}$ diet) exerted no growth promoting effect on rabbits.

\section{Carcass characteristics:-}

Data concerning carcass characteristics are presented in Table 3, it was noted that rabbits drinking $0.39 \mathrm{ml}$ carvacrol/liter had the significantly $(\mathrm{P} \leq 0.05)$ higher relative head weight compared to rabbits drinking $0.13 \mathrm{ml}$ carvacrol/liter or control one. Moreover, rabbits drinking different levels of carvacrol had significantly $(\mathrm{P} \leq 0.05)$ higher relative empty intestinal weight and intestinal length compared to control group. In this respect, the highest and significant values were recorded for rabbits drinking $0.39 \mathrm{ml}$ carvacrol/liter followed by rabbits drinking 0.26 and $0.13 \mathrm{ml}$ carvacrol/liter, respectively, while, the lowest values were recorded for control one. However, there were insignificantly differences due to drinking rabbit different levels of carvacrol in dressing percent and relative weights of carcass, liver, kidneys, heart, lungs and spleen. These results are partially in agreement with results of Ibrahim et al., (2000) who found that adding $0.5 \%$ oregano to rabbit diets increased significantly dressing and giblets \% compared to the control. Also, Janz et al. (2007) reported that improving carcass quality of rabbits associated with feed additives supplementation is likely due to the effects of funnel and oregano bioactive compounds on improving antioxidant status of the rabbits and improving protein and fat metabolism.

Moreover, the active principles of essential oils act as a digestibility enhancer, balancing the gut microbial ecosystem and stimulating the secretion of endogenous digestive enzymes and thus improving growth performance in poultry (Lovkova et al., 2001). On contrast, Omer et al. (2013) showed that dietary oil, fennel seeds and oregano leaves treatments had no significant effect on carcass weight, external offal's included (head, fur, legs, ears, and blood) that presented as \% of slaughter weight and except spleen was significant $(\mathrm{P} \leq 0.05)$ dietary treatments, also, had no significant effect on the other parameters of internal offal's (giblets) included (liver, heart, kidneys, testes and lungs) and dressing percentages. Also, Radwan and Abdel-Khalek (2007) indicated that relative to the slaughter weight, hot carcass, giblets, and total edible parts percentage, were not significantly affected by supplement $0.5 \%$ or $1 \%$ herb mixture composed of equal parts of sage+oregano+sweet basal. Besides, Bampidis 
Table 3: Effect of drinking supplementation of carvacrol on carcass traits of growing rabbit males at 12 weeks of age.

\begin{tabular}{|c|c|c|c|c|c|}
\hline \multirow[t]{2}{*}{ Item } & \multicolumn{4}{|c|}{ Experimental groups } & \multirow[t]{2}{*}{ MSE } \\
\hline & G1 & G2 & G3 & G4 & \\
\hline Carcass weight (\%) & 48.55 & 48.76 & 48.45 & 50.28 & 1.066 \\
\hline Liver weight (\%) & 3.546 & 2.681 & 2.937 & 2.581 & 0.280 \\
\hline Kidneys weight (\%) & 0.862 & 0.805 & 0.858 & 0.709 & 0.068 \\
\hline Heart weight (\%) & 0.311 & 0.375 & 0.400 & 0.339 & 0.043 \\
\hline Lungs weight (\%) & 0.703 & 0.609 & 0.683 & 0.571 & 0.070 \\
\hline Spleen weight (\%) & 0.039 & 0.062 & 0.049 & 0.042 & 0.010 \\
\hline Head weight (\%) & $6.220^{\mathrm{b}}$ & $6.131^{\mathrm{b}}$ & $6.267^{\mathrm{ab}}$ & $6.902^{\mathrm{a}}$ & 0.201 \\
\hline Dressing\% & 53.27 & 52.62 & 52.65 & 53.91 & 1.092 \\
\hline Impiety intestinal weight & $1.436^{\mathrm{c}}$ & $1.859^{\mathrm{bc}}$ & $1.949^{b}$ & $2.448^{\mathrm{a}}$ & 0.134 \\
\hline Intestinal length $(\mathrm{cm})$ & $190.00^{\mathrm{d}}$ & $245.00^{\mathrm{c}}$ & $270.00^{b}$ & $325.0^{\mathrm{a}}$ & 6.770 \\
\hline
\end{tabular}

a, $b \ldots . .$. Means within each row have no similar letter(s) are significantly different $(\mathrm{P} \leq 0.05)$. G1: Control G2: carvacrol (0.13 ml/liter) G3: carvacrol (0.26 ml/liter) G4: carvacrol (0.39 $\mathrm{ml} /$ liter).

et al. (2005) reported that carcass weights, carcass yield, and the relative weights of the heart and liver of turkeys were not significantly affected by oregano content. Also, Ocak et al. (2008) indicated no statistical variations in carcass weight, carcass yield, the relative weights of the edible inner organs and whole gut, and the relative length of the whole gut of broilers fed diets supplemented with thyme.

\section{Hematological picture:}

Table 4 showed that a significant $(\mathrm{P} \leq 0.05)$ increase in the counts of erythrocytes and leukocytic, and hemoglobin, hematocrit value and lymphocytes percent, but no significant differences were detected in neutrophil percentage due to drinking rabbit different levels of carvacrol. In this respect, rabbits drinking $0.39 \mathrm{ml}$ carvacrol/liter recorded the highest count of both erythrocytes and leukocytes, and hemoglobin, hematocrit value and lymphocytes percentage, followed by rabbits drinking 0.26 and $0.13 \mathrm{ml}$ carvacrol/liter, respectively, compared to control group. Concerning, neutrophil/ lymphocytes ratio, rabbits supplemented different levels of carvacrol significantly $(\mathrm{P} \leq 0.05)$ improved neutrophil/ lymphocytes ratio compared to control rabbits. Generally, rabbits drinking $0.39 \mathrm{ml}$ carvacrol/liter recorded the best value of neutrophil/ lymphocytes ratio, followed by rabbits drinking 0.26 and $0.13 \mathrm{ml}$ carvacrol/liter, respectively, compared to control group. In this respect, the heterophil/lymphocytes ratio has been accepted as a reliable index for determining stress in poultry (Maxwell et al. 1998). Heterophils are parts of natural immunity and 
Table 4: Effect of drinking supplementation of carvacrol on hematological parameters in blood of growing rabbit males at 12 weeks of age.

\begin{tabular}{|c|c|c|c|c|c|}
\hline \multirow[t]{2}{*}{ Item } & \multicolumn{4}{|c|}{ Experimental groups } & \multirow[t]{2}{*}{ MSE } \\
\hline & G1 & G2 & G3 & G4 & \\
\hline Red blood cells $\left(\mathrm{N} \times 10^{6 /} \mathrm{mm}^{3}\right)$ & $5.028^{\mathrm{c}}$ & $5.418^{b}$ & $5.706^{b}$ & $6.270^{\mathrm{a}}$ & 0.109 \\
\hline Hemoglobin $(\mathrm{g} / \mathrm{dl})$ & $9.163^{c}$ & $10.292^{b}$ & $10.482^{\mathrm{ab}}$ & $10.710^{\mathrm{a}}$ & 0.154 \\
\hline Hematocrit value (\%) & $34.695^{\mathrm{b}}$ & $36.330^{\mathrm{a}}$ & $36.950^{\mathrm{a}}$ & $36.956^{\mathrm{a}}$ & 0.423 \\
\hline White blood cells $\left(\mathrm{N} \times 10^{3 /} \mathrm{mm}^{3}\right)$ & $5.833^{\mathrm{b}}$ & $6.642^{\mathrm{a}}$ & $6.676^{\mathrm{a}}$ & $6.930^{\mathrm{a}}$ & 0.172 \\
\hline Lymphocytes (\%) & $59.600^{\mathrm{b}}$ & $62.684^{\mathrm{a}}$ & $64.740^{\mathrm{a}}$ & $65.456^{\mathrm{a}}$ & 0.888 \\
\hline Neutrophil (\%) & 33.928 & 33.864 & 33.800 & 33.504 & 0.364 \\
\hline Neutrophil/Lymphocyte ratio & $56.996^{\mathrm{a}}$ & $54.032^{b}$ & $52.248^{\mathrm{bc}}$ & $51.214^{\mathrm{c}}$ & 0.832 \\
\hline
\end{tabular}

a, b.... Means within each row have no similar letter(s) are significantly different $(\mathrm{P} \leq 0.05)$ G1: Control G2: carvacrol (0.13 ml/liter) G3: carvacrol ( $0.26 \mathrm{ml} /$ liter $)$ G4: carvacrol (0.39 $\mathrm{ml} /$ liter).

cellular defense against microbial infections, and lymphocytes are cells that produce antibodies and cytokines.

The increases in heterophil/lymphocytes ratio in challenged chicks may be attributed to increased corticosterone secretion (Vleck and Bucher, 2000), which finally resulted in decrease of the antibody titers. In contrast to our results, Al-Kassie (2009) showed that feeding diets were supplemented with oil extract derived from thyme and cinnamon to broilers, which significantly increased $\mathrm{RBC}, \mathrm{HCT}, \mathrm{Hb}$ and $\mathrm{WBC}$ values compared with the control group. However, Toghyani et al. (2010) found that the red and white blood cell counts, hemoglobin concentration, hematocrit percentage and heterophil to lymphocyte ratio did not differ significantly among treatments. However, hematological parameters are usually related to health status and are of diagnostic importance in clinical evaluation of the state of health. Also, hematological parameters are good indicators of physiological, pathological and nutritional status of animal and changes in hematological parameters have the potential of being used to elucidate the impact of nutritional factors and additives supplied in diet on any living creature. For example, leucocytes are known to increase sharply when infection occurs, as they are one of the first lines of defense of the body (Ganong, 1999).

\section{Microbiological analysis:-}

Significant $(\mathrm{P} \leq 0.05)$ improvement was detected due to drinking rabbit different levels of carvacrol (Table 5). The obtained results indicated that both total anaerobic and Escherichia coli (E. coli) counts of bacteria were significantly $(\mathrm{P} \leq 0.05)$ decreased, while lactobacillus count was significantly $(\mathrm{P} \leq 0.05)$ increased by drinking rabbit different levels of carvacrol when compared to undrinking control group. However, no significant $(\mathrm{P} \leq 0.05)$ 
Table 5: Effect of drinking supplementation of carvacrol on cecal bacteria count of New Zealand White rabbit males at 12 weeks of age.

\begin{tabular}{|c|c|c|c|c|c|}
\hline \multirow[t]{2}{*}{ Items } & \multicolumn{4}{|c|}{ Experimental groups } & \multirow[t]{2}{*}{ MSE } \\
\hline & G1 & G2 & G3 & G4 & \\
\hline Total anaerobic bacteria $\left(\times 10^{6}\right)$ & $7.778^{\mathrm{a}}$ & $7.156^{\mathrm{b}}$ & $7.094^{b}$ & $6.864^{\mathrm{b}}$ & 0.081 \\
\hline Lactobacilli $\left(\times 10^{6}\right)$ & $3.348^{\mathrm{c}}$ & $3.836^{\mathrm{b}}$ & $4.010^{\mathrm{ab}}$ & $4.304^{\mathrm{a}}$ & 0.113 \\
\hline Escherichia coli $\left(\times 10^{2}\right)$ & $793.20^{\mathrm{a}}$ & $736.17^{b}$ & $711.23^{b c}$ & $686.40^{\mathrm{c}}$ & 9.813 \\
\hline
\end{tabular}

differences were found between different levels of carvacrol on total anaerobic, lactobacillus and Escherichia coli (E. coli) counts of bacteria. Generally, rabbits drinking $0.39 \mathrm{ml}$ carvacrol/liter recorded the lowest counts of both anaerobic and E. coli bacteria, and the highest count of lactobacillus followed by rabbits drinking 0.26 and $0.13 \mathrm{ml}$ carvacrol/liter, respectively, compared to control group. These results are closely in agreement with the results of Roofchaee et al. (2011) who reported that there were no statistically significant differences among oregano essential oil treatments regarding populations of cecal lactic acid bacteria.

On the other hand, supplementation of 300 and $600 \mathrm{mg} / \mathrm{kg}$ of oregano essential oil significantly $(\mathrm{P} \leq 0.05)$ lowered cecal $E$. coli populations compared with both the control and $1200 \mathrm{mg} / \mathrm{kg}$ of oregano essential oil supplemented groups. Besides, Cross et al. (2007) showed that supplementation of $1 \mathrm{~g} / \mathrm{kg}$ oregano essential oil in broiler's diet, could not affect cecal populations of lactic acid bacteria. Generally, there are limited numbers of in vivo studies about the effects of oregano essential oil on the intestinal microflora of broiler chickens. Where, Abdel-Wareth (2011) indicated that oregano had increased Lactobacillus population in crop and small intestine digesta of broilers. Nevertheless, Penalver et al. (2005) reported that in their in vitro study essential oil of oregano incredibly exerted antibacterial effect against poultry origin strains of $E$. coli. They also suggested that this potent antibacterial activity can widely be attributed to the presence of two major active components of oregano essential oil that is, thymol and carvacrol. Also, Helander et al. (1998) investigated the antibacterial mechanism of two major components of oregano essential oil, carvacrol and thymol on E. coli and reported both carvacrol and thymol, in a similar mechanism, disintegrate the membrane of bacteria, leading to the release of membrane associated materials to the external medium. They also suggested that thymol and carvacrol are able to penetrate the bacteria and may thus, be able to influence their proliferation. As thyme has been 
reported to have antibacterial and antifungicidal activities (Vincent, 2002; Basilico and Basilico, 1999) and the major components of thyme essential oil thymol and carvacrol have been indicated to increase in immune responses of chicks.

In conclusion, the results of the present study suggested that drinking rabbit different levels of carvacrol to rabbit males was efficient in improving the growth performance traits, carcass characteristic and had beneficial effects on some immunological responses during growth period.

\section{REFERENCES}

Adam, K., Sivropoulou, A., Kokkini, S., Lanaras, T. and Arsenakis, M. (1998). Antifungal activities of Origanum vulgare subsp. hirtum, Mentha spicata, Lavandula angustifolia, and Salvia fruticosa essential oil against human pathogenic fungi. J. Agric. Food Chem., 46:1739-1745.

Abdel-Wareth, A.A.A. (2011). Effect of thyme, oregano and their major active components on performance and intestinal microbial populations of broilers. Ph.D. Faculty of Agriculture, Rheinische Friedrich-Wilhelms-Universität, Bonn, Germany.

Alagawany, MM, Farag MR, Dhama K, Abd El-Hack, ME, Tiwari R, Alam GM (2015a). Mechanisms and Benefcial Applications of Resveratrol as Feed Additive in Animal and Poultry Nutrition: A Review. Int. J. Pharmacol., 11: 213-221.

Alagawany, MM, Farag MR, Dhama K (2015b). Nutritional and biological effects of turmeric (Curcuma longa) supplementation on performance, serum biochemical parameters and oxidative status of broiler chicks exposed to endosulfan in the diets. Asian J. Anim. Vet. $A d v ., 10: 86-96$.

Al-Kassie, GAM (2009). Influence of two plant extracts derived from thyme and cinnamon on broiler performance. Pak. Vet. Journal, 29(4): 169-173.

Arcila-Lozano, C.C., G. Loarca - Pina, S. Lecona -Uribe and E. Gonzalez de Mejia (2004). Oregano: Properties, composition and biological activity. Arch Latinoam Nutr., 54: 100-111.

Ashour, EA, Alagawany M, Reda FM, Abd El-Hack, ME (2014). Effect of Supplementation of Yucca schidigera Extract to Growing Rabbit Diets on Growth Performance, Carcass Characteristics, Serum Biochemistry and Liver Oxidative Status. Asian J. Anim. Vet. Adv., 9: 732-742. 
Bampidis, V.A., V. Christodoulou, P. Florou-Paneri, E. Christaki, P.S. Chatzopoulou, T. T. Siligianni and A.B. Spais (2005). Effect of dietary dried oregano leaves on growth performance, carcass characteristics and serum cholesterol of female early maturing turkeys. Br. Poult. Sci., 46 (5): 595-601.

Basilico, M.Z. and J.C. Basilico, (1999). Inhibitory effect of some spice essential oils on Aspergillus ochraceus NRRL3174 growth and ochratoxin A production. Lrtt. Appl. Microbiol., 29: 238-241.

Botsoglou, N.A., Florou-Paneri, P., Christaki, E., Fletouris, D.J. and Spais, A.B., (2002). Effect of dietary oregano essential oil on performance of chickens and on iron-induced lipid oxidation of breast, thigh and abdominal fat tissues. Br. Poult. Sci., 43:223-230.

Botsoglou, NA., Florou-Paneri, P. Christaki, E., Giannenas, I. and Spais, AB. (2004). Performance of rabbits and oxidative stability of muscle tissues as affected by dietary supplementation with oregano essential oil. Arch. Anim. Nutr., 58 (3): 209-218.

Bravo D, Pirgozliev V, Rose SP (2014). A mixture of carvacrol, cinnamaldehyde, and capsicum oleoresin improves energy utilization and growth performance of broiler chickens fed maize-based diet. Journal of Anim. Sci., 92(4): 1531-1536.

Cheeke, P.R. (1987). Rabbit feeding and nutrition. Academic Press, INC.

Collins, C.H; Lyne, P.M. and Grange, J.M. (1995). Collins Andlyne's Microbiological Methods. Butterworth Heinemann Ltd, Oxford.512 p.

Cox, SD. and Markham, JL. (2007). "Susceptibility and intrinsic tolerance of Pseudomonas aeruginosa to selected plant volatile compounds". J. Appl. Microbiol. ,103 (4): 930-6.

Cross, DE, McDevitt, RM, Hillman, K. and Acamovic, T. (2007). The effect of herbs and their associated essential oils on performance, dietary digestibility and gut microflora in chickens from 7 to 28 days of age. Br. Poult. Sci., 48: 496-506.

Dhama, K.; Shyma, K.; Latheef, Saminathan, M.; Abdul Samad, H.;, Karthik, K.; Tiwari, R.; Khan, RU.; Alagawany, M.; Farag, MR.; Alam, GM.; Laudadio, V. and Tufarelli, V. (2015). Multiple beneficial applications and modes of action of herbs in poultry health and production-A review. Int. J. Pharmacol., 11: 152-176.

Drew, P.; R.J.S. Charles; B. Trevor and L. John, (2004). Oxford Handbook of Clinical Haematology. 2th Edition, Oxford University Press, USA.

Duncan, D.B.(1955).Multiple range and multiple F-tests. Biometrics, 11:1-42. 
Du WX, Olsen CE, Avena-Bustillos RJ, McHugh TH, Levin CE, Friedman M. (2008). Storage stability and antibacterial activity against Escherichia coli $\mathrm{O} 157: \mathrm{H} 7$ of Carvacrol in edible apple films made by two different casting methods". J. Agric. Food Chem.,56 (9): 3082-3088. doi:10.1021/jf703629s. PMID 18366181.

Ertas, O.N., Güler, T., Ciftci, M., Dalkilic, B., Simsek, U.G. (2005). The effect of an essential oil mix derived from oregano, clove and anise on broiler performance. Int. J. Poultry Sci., 4: 879-884.

Farag, MR., Alagawany, MM. and Dhama, K. (2014). Antidotal efect of Turmeric (Curcuma longa) against endosulfan-induced cytogenotoxicity and immunotoxicity in broiler chicks. Int. J. Pharmacol., 10: 429-439.

Feldman, B.F., J.G. Zinkl, and N.C. Jain, (2000). Schalm's Veterinary Hematology. Lippincott Williams and Wilkins, Philadelphia, USA.

Ganong, WF (1999). Review of Medical Physiology. 19th ed. Stanford, Connecticut, Appleton and Lange, p. 353.

Hashemipour, HI., Kermanshahi, H., Golian, A. and Veldkamp, T. (2013). Effect of thymol and carvacrol feed supplementation on performance, antioxidant enzyme activities, fatty acid composition, digestive enzyme activities, and immune response inbroiler NE US Academi Publishers Advances in Animal and Veterinary Sciences March 2015 | Volume 3 | Special issue 2 | Page 82chickens. Poultry Sci. 92(8):2059-69.

Helander, IM., Alakomi, HL., Latva-Kala, K., Mattila-Sandholm, T., Pol, I., Smid, EJ., Gorris, LGM. and Von Wright, A. (1998). Characterization of the action of selected essential oil components on gram negative bacteria. J. Agric. Food Chem., 46: 3590- 3595.

Ibrahim, Sh. A., El-Fiky, A. A., Abou-El-Ella, A. A. (2002). Sage and yarrow as natural bio-stimulators and detoxicants against lead in growing rabbit diets. 3rd International Conference on Rabbit Production in Hot Climates, Egypt, pp. 541-555.

Ibrahim, Sh. A., El-Ghamry, A.A., El-Mallah, G.M. (2000). Effect of some plants of Labiatae family as feed additives on growth and metabolic changes of rabbits. Egyptian J. Rabbit Sci., 10 (1): 105-120.

Jamali, CA., El Bouzidi, L., Bekkouche, K., Lahcen, H., Markouk, M., Wohlmuth, H., Leach, D. and Abbad, A. (2012). Chemical composition and antioxidant and anticandidal activities of essential oils from different wild Moroccan Tymus species. Chem. Biodivers., 9(6): 1188-1197. 
Janz, J.A. M., P.C.H. Morel, B.H.P. Wilknson and R.W. Purchas (2007). Preliminary investigation of the effects of low-level dietary inclusion of fragrantessential oils and oleoresins on pig performance and pork quality. Meat Sci., 75: 350-355.

Karpouhtsis, I., Pardali, E., Feggou, E., Kokkini, S., Scouras, ZG., Mavragani-Tsipidou, P. (1998). Insecticidal and genotoxic activities of oregano essential oils. J. Agric. Food Chem., 46:1111-1115.

Kim, H.U.; and Goepfert, J.M. (1971). Enumeration and identification of bacillus cereus in foods,1,24-hours presumptive test edium. Appl. Microbiol., 22:581-587.

Kim, E., Choi, Y., Jang, J. and Park, T. (2013). Carvacrol protects against hepatic steatosis in mice fed a high-fat diet by enhancing SIRT1-AMPK signalling. Evid. Based Complement. Alternat. Med., 1-10.

Lambert, RJW., Skandamis, PN., Coote, PJ. and Nychas, GJE. (2001). A study of the minimum inhibitory concentration and mode of action of oregano essential oil, thymol and carvacrol. J. Appli. Microbiology, 91:453-462.

Lee, KW.; Everts, H.; Kappert, H. J.; Frehner, M.; Losa, R. and Beynen, AC. (2003a). Effects of dietary essential oil components on growth performance, digestive enzymes and lipid metabolism in female broiler chickens. Br. Poult. Sci., 44: 450-457.

Lee, K.W., H.Everts, H.J. Kappert, K.H. Yeom and A.C. Beynen, (2003b). Dietary carvacrol lowers body weight gain but improves feed conversion in female broiler chickens. J. Appl. Poult. Res., 12: 394-399.

Lovkova, M.Y., Buzuk G.N., Sokolova S.M., Kliment'eva N.I. (2001). Appl. Biochem. Microbiol., 37: 229-237.

Mansoub, (2011). Performance, carcass quality, blood parameters and Immune System of broilers fed diets supplemented with oregano oil (Origanum sp.). Annals of Biological Research, 2 (6):652-656.

Maxwell, M.H.; and Robertson, G.W., 1998. The avian heterophil leukocyte: A review. World's Poultry Sci. J., 54: 155-178.

Milos, M., Mastelic, J. and Jerkovic, I. (2000). Chemical composition and antioxidant effect of glycosidically bound volatile compounds from oregano (Origanum vulgare L. ssp. hirtum). Food Control, 71:79-83.

Moleyar, V. and Narasimham, P. (1992). Antibacterial activity of essential oil components. International Journal, ارقام الصفحات.

NRC, (1994): Nutrient Requirements of Poultry. 9th Rev. National Research Council, National Academy Press. Washington, DC, USA. 
Ocak, N., Erener, G., Burak, AkF., Sungu, M., Altop, A. and Ozmen, A. (2008). Performance of broilers fed diets supplemented with dry peppermint (Mentha piperita L.) or thyme (Thymus vulgaris L.) leaves as growth promoter source. Czech J. Animal Sci., 53(4): 169-175.

Omer, H.A.A., , Y.A.A. EL-Nomeary, R.I. EL-Kady, Azza M.M. Badr, F.A.F. Ali, Sawsan M. Ahmed, H.M.H. EL-Allawy and Sh. A.M. Ibrahim (2013). Improving the Utilization of Rabbit Diets Containing Vegetable Oil by Using Fennel (Foeniculum vulgare) and Oregano (Origanum vulgare L) as Feed Additives. Life Science Journal, 10 (1):2625-2636.

Penalver, P., Huerta, B., Borge, C., Astorga, R., Romero, R. and Perea, A. (2005). Antimicrobial activity of five essential oils against origin strains of the Enterobacteriaceae family. APMIS, 113:1-6.

Radwan, N.L. and A.M. Abdel - Khalek, (2007). Response of summer stressed growing rabbits to some dietary growth promoters. Tartu Estonia "Animal health, animal welfare and biosecurity", 1: 350-358.

Reiner, GN., Labuckas, DO. and Garcia, DA. (2009). Lipophilicity of some GABAergic phenols and related compounds determined by HPLC and partition coefcients in diferent systems. J. Pharm. Biomed. Anal. 49: 686-691.

Rhee, KS., Anderson, LM. and Sams, AR. (1996). Lipid peroxidation potential of beef, chicken and pork. J. Food Sci., 61: 8-12.

Roofchaee, A., Irani, M., Ebrahimzadeh, M.A. and Akbari, M.R. (2011). Effect of dietary oregano (Origanum vulgare L.) essential oil on growth performance, cecal microflora and serum antioxidant activity of broiler chickens. African J. of Biotechnology, 10 (32):6177-6183.

SAS institute, (2001). SAS Users Guide Statistics. Version $10^{\text {th }}$, 16- Edition, SAS Inst., Cary, NC.

Soultos, N. Z. Tzikas, E. Christaki, K. Papageorgiou and V. Steris (2009). The effect of dietary oregano essential oil on microbial growth of rabbit carcasses during refrigerated storage. Meat Science, 81: 474-478.

Thompson, DP. (1989). Fungitoxic activity of essential oil components on food storage fungi. Mycologia, 81:151-153.

Toghyani, M., M. Tohidi1, A. A. Gheisari and S. A. Tabeidian (2010). Performance, immunity, serum biochemical and hematological parameters in broiler chicks fed dietary thyme as alternative for an antibiotic growth promoter. African Journal of Biotechnology, 9(40): 6819-6825. 
Ultee, A. and Smid, EJ. (2001). "Influence of carvacrol on growth and toxin production by Bacillus cereus". Int. J. Food Microbiol., 64 (3): 373-8.

Untea, A., R. Criste, T. Panaite and I. Costache (2011). Effect of the dietary oregano (Origanum vulgare) on $\mathrm{Cu}$ and $\mathrm{Zn}$ balance in weaned piglets. Journal of Trace Elements in Medicine and Biology, 25S: S35-S40.

Vekiari, S.A., Oreopoulou, V., Tzia, C. and Thomopoulos, C.D. (1993). Oregano flavonoids as lipid antioxidants. J. Am. Oil. Chem. Soc., 70:483-487.

Vincent, HV. (2002). Carvacrol and thymol reduce swine waste odour and pathogens stability of oils. Curr. Microbiol., 44: 38-43.

Vleck, D.; and Bucher, T.L., 2000. Stress, corticosterone, and heterophil to lymphocyte ratios in free living A delie penguins. The Condor, 102: 392-400.

Vokou, S., Kokkini, S. and Bessiere, J.M. (1993). Geographic variation of Greek oregano (Origanum vulgare subsp. hirtum) essential oils. Biochem. Syst. Ecol., 21:287-295.

Yanishlieva, NV., Marinova, EM., Gordon, MH. and Raneva, VG. (1999). Antioxidant activity and mechanism of action of thymol and carvacrol in two lipid systems. Food Chem., 64: 59-66.

$$
\begin{aligned}
& \text { تأثير الكارفاكرول على الآداء الانتاجى وبعض الصفات المناعية }
\end{aligned}
$$

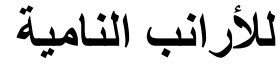

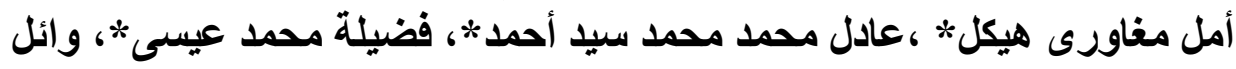

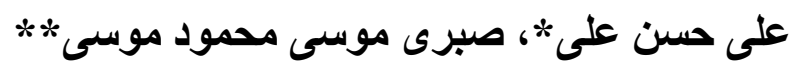

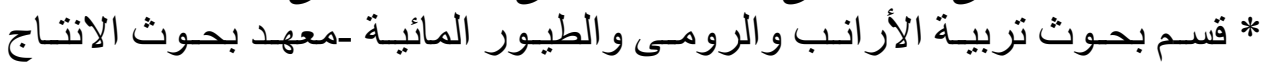

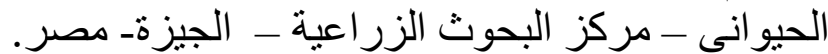

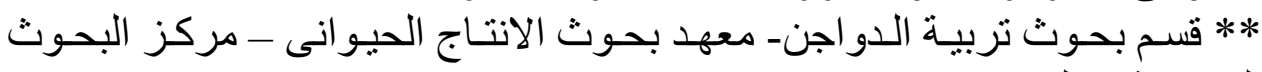

$$
\begin{aligned}
& \text { الزر اعية - الجيزة مصن مصر. }
\end{aligned}
$$

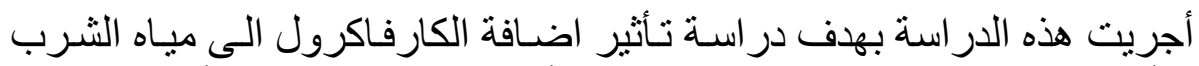

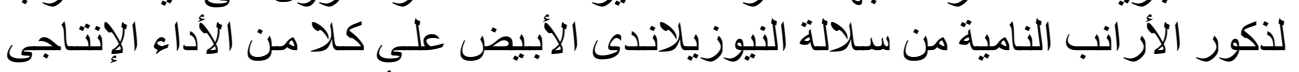

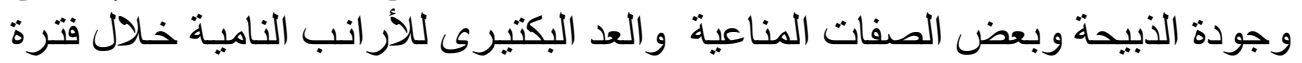

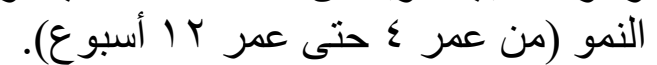

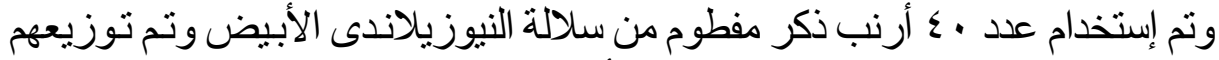

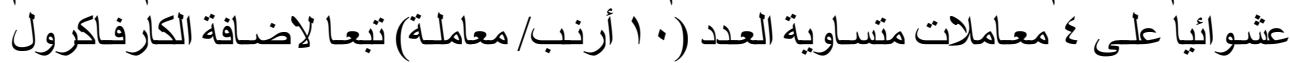

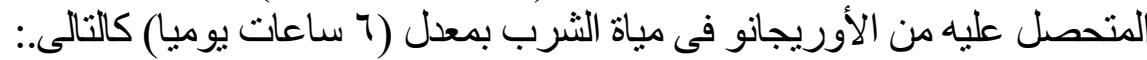

$$
\begin{aligned}
& \text { 1 ـ المجمو عة الأولى: (كنترول) تشرب ماء عادى دون إضى إضافة الكار فاكرول إلى مياه الثرب. }
\end{aligned}
$$


EFFECT OF CARVACROL ON GROWING RABBITS

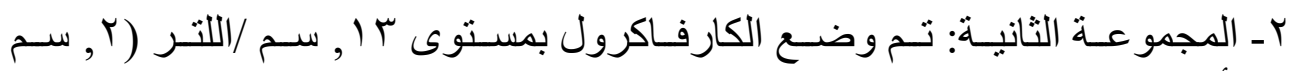

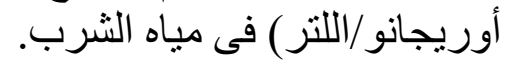

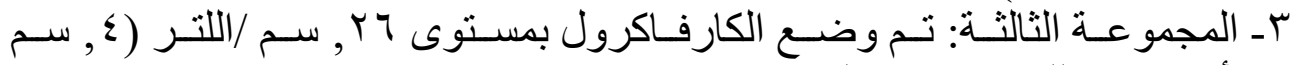

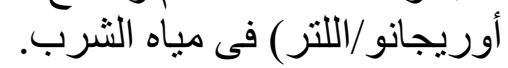

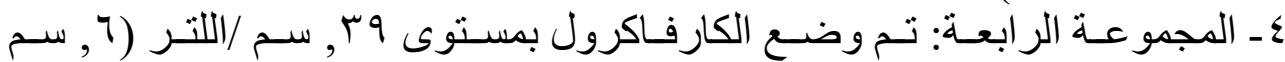

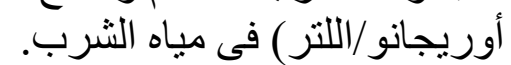

وكاتت أهم النتائج المتحصل في علياه عليهاكالأتى:

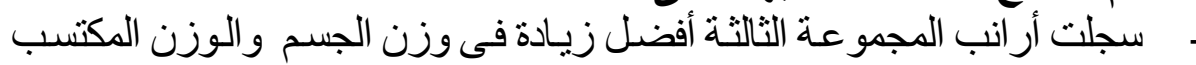

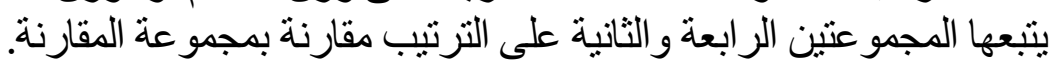

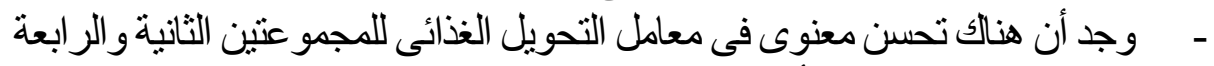

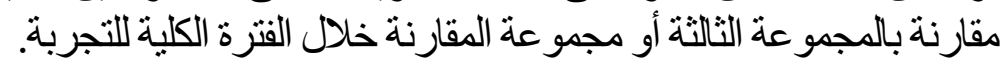

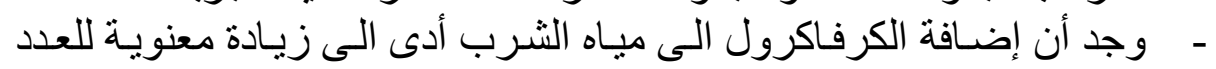

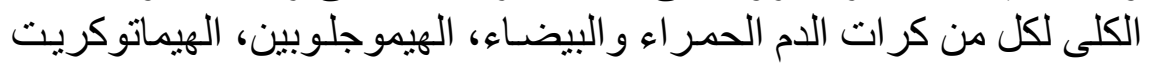

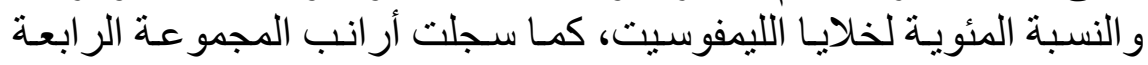

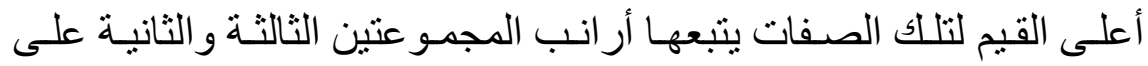
الترتيب وذلك مقارنة بمجمو عة المقارنة.

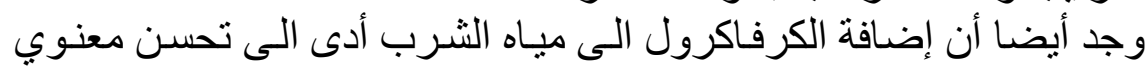

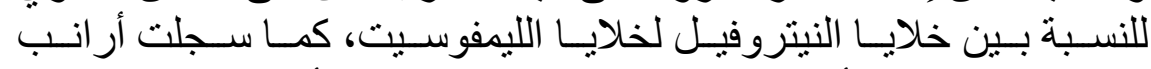

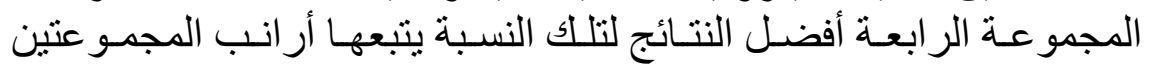

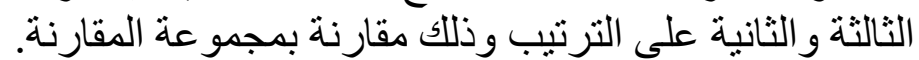

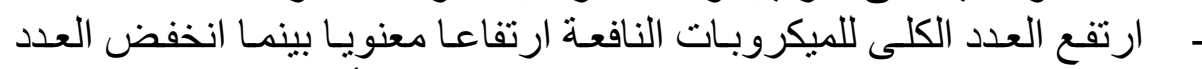

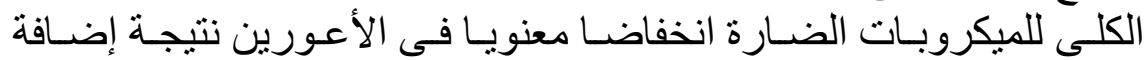

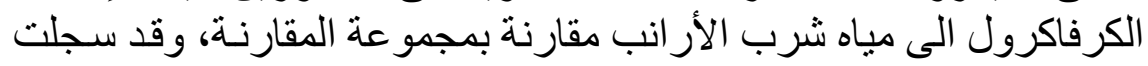

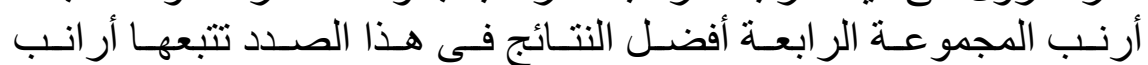

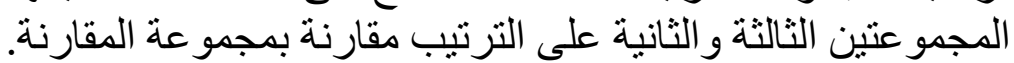

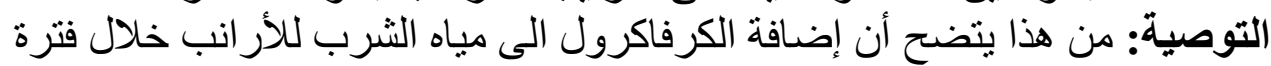

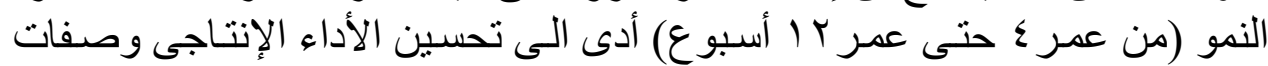

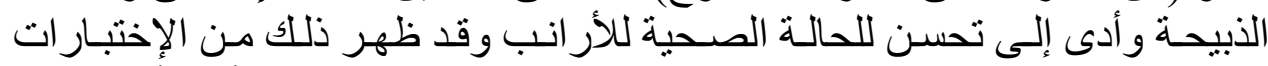

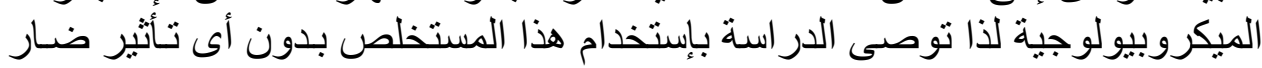

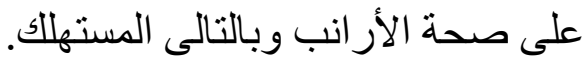

